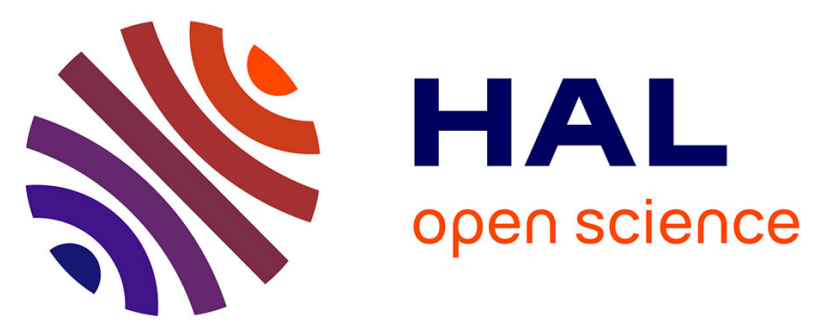

\title{
A set of PCRs for rapid identification and characterization of Pseudomonas syringae phylogroups
} Benoit Borschinger, Claudia Bartoli, Charlotte Chandeysson, Caroline Guilbaud, Luciana Parisi, Jean-François Bourgeay, Elise Buisson, Cindy E. Morris

\section{To cite this version:}

Benoit Borschinger, Claudia Bartoli, Charlotte Chandeysson, Caroline Guilbaud, Luciana Parisi, et al.. A set of PCRs for rapid identification and characterization of Pseudomonas syringae phylogroups. Journal of Applied Microbiology, 2016, 120 (3), pp.714-723. 10.1111/jam.13017 . hal-01444672

\section{HAL Id: hal-01444672 \\ https://hal.science/hal-01444672}

Submitted on 27 May 2020

HAL is a multi-disciplinary open access archive for the deposit and dissemination of scientific research documents, whether they are published or not. The documents may come from teaching and research institutions in France or abroad, or from public or private research centers.
L'archive ouverte pluridisciplinaire HAL, est destinée au dépôt et à la diffusion de documents scientifiques de niveau recherche, publiés ou non, émanant des établissements d'enseignement et de recherche français ou étrangers, des laboratoires publics ou privés.

\section{(c) (1) $\$$}

Distributed under a Creative Commons Attribution - NonCommerciall 4.0 International 
Received Date : 07-Sep-2015

Revised Date : 29-Oct-2015

Accepted Date : 26-Nov-2015

Article type : Original Article

\title{
A set of PCRs for rapid identification and characterization of Pseudomonas syringae phylogroups
}

\author{
B. Borschinger ${ }^{1,2}$, C. Bartoli ${ }^{3,4}$, C. Chandeysson ${ }^{1}$, C. Guilbaud ${ }^{1}$, L. Parisi ${ }^{1}$, J.F. Bourgeay ${ }^{1}$, E. \\ Buisson $^{2}$, C.E. Morris ${ }^{1 *}$ \\ 1-INRA, Unité de Pathologie Végétale, Domaine de St Maurice, BP 94, 84140 Montfavet, France \\ 2-IMBE, Université d'Avignon et des Pays de Vaucluse, UMR CNRS IRD Aix Marseille Université, Site Agroparc BP \\ 61207, 84911 Avignon, France \\ 3-INRA, Laboratoire des Interactions Plantes-Microorganismes (LIPM), UMR441, F-31326 Castanet-Tolosan, France \\ 4-CNRS, Laboratoire des Interactions Plantes-Microorganismes (LIPM), UMR2594, F-31326 Castanet-Tolosan, France
}

\section{Abbreviated running headline}

PCR for Pseudomonas syringae phylogroups

* Corresponding author: cindy.morris@ paca.inra.fr

\section{Abstract}

Aims: The aim of this study was to develop a rapid PCR-based method for the specific detection of individual phylogroups of the Pseudomonas syringae complex.

Methods and Results: Seven primer pairs were developed by analyzing whole genomes of $54 P$.

syringae strains. The specificity and sensitivity of these primer pairs were assessed on 236 strains from a large and comprehensive $P$. syringae collection. The method was also validated by

This article has been accepted for publication and undergone full peer review but has not been through the copyediting, typesetting, pagination and proofreading process which may lead to differences between this version and the Version of Record. Please cite this article as an 'Accepted Article', doi: 10.1111/jam.13017

This article is protected by copyright. All rights reserved. 
characterizing the phylogenetic diversity of 174 putative $P$. syringae isolates from kiwifruit and apricot orchards of southeastern France.

Conclusion: Our PCR-based method allows for the detection and characterization of 9 of the $13 P$. syringae phylogroups (phylogroups 1, 2, 3, 4, 7, 8, 9, 10 and 13).

Significance and Impact of the Study: To date, phylogenetic affiliation within the $P$. syringae complex was only possible by sequencing housekeeping genes. Here we propose a rapid PCR-based method for the detection of specific phylogroups of the $P$. syringae complex. Furthermore, for the first time we reveal the presence of $P$. syringae strains belonging to phylogroups 10 and 13 as epiphytes on plants whereas they had previously only been observed in aquatic habitats.

\section{Keywords}

Plant pathogen, microbial ecology, pathobiome, multiplex PCR, orchards

\section{Introduction}

In plant pathology, competitive or synergistic interactions among microorganisms have been disregarded in disease etiology. The emerging pathobiome concept pointed out that etiological agents can work in concert with indigenous microflora to induce disease (Vayssier-Taussat et al. 2014). The impact on disease of infra-specific diversity of microorganisms in individual hosts has been ignored. In the case of plant pathogenic bacteria, analyses of the structure of the pathogenic populations generally concern the metapopulation/population at large in a region (Scortichini 2005), but rarely addresses the structure of pathogen populations in individual plants. Phenomena of gain of fitness, as well as synergistic interactions, are not uncommon within strains of different genetic lines belonging to the same bacterial species and could enhance diseases (Kamoun and Kado 1990; Hirano et al. 1999; Scortichini 2005; Lamichhane and Venturi 2015). On the other hand, competition between strains of the same ecological niche could attenuate disease symptoms (Kerr and Htay 1974; Moss et al. 2007; Kawaguchi et al. 2014). In spite of these observations, conventional diagnosis of plant diseases has

This article is protected by copyright. All rights reserved.

Borschinger, B., Bartoli, C., Chandeysson, C., Guilbaud, C., Parisi, L., Bourgeay, J.-F. 
focused on the characterization of the dominant organisms in infected tissue. To address the issue of microbial complexes responsible for disease occurrence, detection methods that facilitate the assessment of the population structure in individual plants are needed. In addition, metagenomics approaches are in part unable to characterize the structure of different microbial communities at species level (Handelsman 2004; Walker et al. 2014; Barret et al. 2015). In light of these facts, we have developed a set of PCRs to rapidly identify the phylogenetic structure of the plant pathogenic bacterium Pseudomonas syringae (Berge et al. 2014). This method requires strain isolation, thereby allowing subsequent evaluation of the pathogenicity of the isolated strains.

P. syringae is a common environmental bacterium that is ubiquitous in both aquatic and agricultural habitats where it can have both saprophytic and pathogenic behavior. P. syringae is also an important plant pathogen causing diseases such as kiwifruit canker reported in all kiwi-producing regions: Australasia, Europe and South America (Hirano and Upper 1990; Gaignard and Luisetti 1993; Vanneste 2013; Donati et al. 2014). Since the beginning of the $20^{\text {th }}$ century, 55 cases of bacterial diseases in 25 countries and on 25 species of trees of agronomic importance were declared as being caused by this bacterium (Lamichhane et al. 2014). Likewise, in this same period P. syringae has been identified as the cause of nearly 70 new disease outbreaks affecting over 40 annual crop species (Lamichhane et al. 2015).

P. syringae is now recognized as a complex of at least 13 phylogroups (Berge et al. 2014). Each phylogroup displays unique phenotypes and it can be distinguished according to the sequence of one (for example citrate synthase) or a few (Multilocus Sequence Typing) housekeeping genes (Berge et al. 2014). Studies on the non-agricultural habitats (water, litter, wild plants, etc) showed that multiple P. syringae phylogroups can co-exist in the same sample (Morris et al. 2007; Monteil et al. 2013). However, there is a paucity of information about such co-existence in crops and about the possible role of co-existing strains in disease occurrence. In light of the current well-defined $P$. syringae classification and the numerous whole genome sequences that are available (Berge et al. 2014), we have sought to develop PCR primers that target as many of the phylogroups as possible to facilitate analysis of the $P$. syringae populations associated with diseased plants as well as with a range of environmental substrates. These molecular markers are more encompassing than those that have been

This article is protected by copyright. All rights reserved.

Borschinger, B., Bartoli, C., Chandeysson, C., Guilbaud, C., Parisi, L., Bourgeay, J.-F. 
developed to detect genetic lines that have pathovar names such as $P$. syringae pv. phaseolicola (Mosqueda-Cano and Herrera-Estrella 1997), P. syringae pv. tomato (Zaccardelli et al. 2005), P. syringae pv. aesculi (Green et al. 2009) and P. syringae pv. actinidiae (Sawada et al. 1997; Sawada et al. 1999; Koh and Nou 2002; Rees-George et al. 2010; Gallelli et al. 2011; Balestra et al. 2013; Gallelli et al. 2014; Loreti et al. 2014). Pathovar-specific markers could nevertheless be used in conjunction with phylogroup markers and also with the "universal" marker of all members of the $P$. syringae complex (Guilbaud et al., in press). This latter primer pair, called "Psy", allows for the identification of strains in the P. syringae complex with over $97 \%$ accuracy. This allows a real gain in time when identifying strains of $P$. syringae. However

, this latter method does not identify the phylogroup affiliation of $P$. syringae.

Here, we propose a set of molecular markers identifying each of 9 major $P$. syringae phylogroups based on the current phylogenetic classification and the genomes of $P$. syringae accessible in public databases. We also describe a method to deploy these markers in a multiplex-PCR with the Psy primer set as a universal control for reliable detection and identification of $P$. syringae phylogroups. An example of the use of this method to characterize communities of $P$. syringae associated with kiwifruit and apricot plant samples from southeastern France is also reported.

\section{Materials and Methods}

Strains and criteria used for primer design

During this study 439 strains were used for 3 different objectives: i) to develop the primer pairs, ii) to validate the designed primers (specificity/sensitivity), and iii) to perform a "blind test" for the multiplex-PCR method on putative $P$. syringae isolates obtained from kiwifruit and apricot orchards from southeastern France. For primer development, DNA sequences were identified in whole genomes of 54 P. syringae strains (Table S1) available on the Joint Genome Institute (JGI) platform

This article is protected by copyright. All rights reserved.

Borschinger, B., Bartoli, C., Chandeysson, C., Guilbaud, C., Parisi, L., Bourgeay, J.-F. 
(http://jgi.doe.gov/). The distribution of the corresponding strains within the various phylogroups is uneven and reflects the availability of the sequences.

To evaluate the specificity and sensitivity of the primer pairs, 236 strains whose phylogroups were previously determined by citrate synthase (cts) gene sequencing, were used (Table S1). These 236 strains are part of the P. syringae collection of the Plant Pathology research Unit of the INRA PACA Avignon center. This collection is composed by over 7000 P. syringae strains isolated from crops and non-agricultural habitats.

Strains were maintained at $-80^{\circ} \mathrm{C}$ in phosphate buffer containing $20 \%$ glycerol and were cultured on King's B medium (King et al. 1954) and incubated at $25^{\circ} \mathrm{C}$ for 48 hours prior each analysis. The strains used for primer development and for the specificity and sensitivity tests were pure culture strains.

Putative $P$. syringae isolates, not pure culture strains, were used for the "blind test" described below. These putative $P$. syringae isolates came from field sampling aiming to characterize $P$. syringae populations associated with kiwifruit and apricot orchards in southeastern France (Drôme county). Overall 174 putative $P$. syringae isolates were used. These isolates were collected from different substrates including leaves, buds, twigs, ground-cover, soil and irrigation waters (Table S1). For bacterial isolation, leaf, bud, twig and ground cover samples were homogenized with a stomacher in a phosphate buffer solution for 4 minutes. Soil samples were directly suspended with sterilized distilled water. Bacterial isolation from water samples was carried out according to the method previously described (Morris et al. 2010). For all the obtained suspensions, we performed dilution-plating on a modified King's B medium (KBC) (Mohan and Schaad 1987). KBC as used in this study was composed of 9 volumes of King's B medium with a smaller quantity of proteose peptone than the original recipe $\left(1.5 \mathrm{~g} \mathrm{~K}_{2} \mathrm{HPO}_{4}, 1.5 \mathrm{~g} \mathrm{MgSO}_{4} 7 \mathrm{H}_{2} \mathrm{O}, 15 \mathrm{~g}\right.$ proteose-peptone, $10 \mathrm{ml}$ glycerol and $16 \mathrm{~g}$ agar in $900 \mathrm{ml}$ distilled water), and 1 volume of boric acid (1.5 $\mathrm{g} \mathrm{H}_{3} \mathrm{BO}_{3}$ in $100 \mathrm{ml}$ distilled water), and contains cycloheximide $\left(200 \mathrm{mg}^{-1}\right)$ and cephalexin $\left(80 \mathrm{mg} \mathrm{l}^{-1}\right)$. The plates were incubated at $25^{\circ} \mathrm{C}$ for 48-72 hours. Putative P. syringae isolates were identified by the morphology of the colony (size, color, reflectance of light and roughness of the colony border). These isolates were stored in a phosphate buffer. No previous data about their phylogroup affiliation were available for these isolates.

This article is protected by copyright. All rights reserved.

Borschinger, B., Bartoli, C., Chandeysson, C., Guilbaud, C., Parisi, L., Bourgeay, J.-F. Buisson, E., Morris, C. E. (Auteur de correspondance) (2016). A set of PCRs for rapid identification and characterization of Pseudomonas syringae phylogroups. Journal of Applied Microbiology, 120 
Phylogroup affiliation of these isolates was verified by sequencing the cts gene of the corresponding purified strain of each isolate. The resulting cts sequences were aligned with the $c t s$ sequences of the strains from the $P$. syringae collection described above ( 1 or 2 representatives per phylogroup) by using clustalW2 software. A phylogenetic tree was constructed with the Neighbor Joining Model and 3000 bootstrap replicates by using MEGA6 software (Tamura et al. 2013).

Fifty-four $P$. syringae whole genomes available on the JGI platform and representative of 10 phylogroups were used to identify genes specific for each phylogroup with the IMG/M system (http://img.jgi.doe.gov). The Abundance Profile Overview tool was used in order to identify unique genes specific for each phylogroup. This tool provides an overview of the relative abundance of protein families (COGs and Pfams) across the 54 selected genomes used in this study. Genes selected for primer designing are listed in Table 1. All gene sequences used in this study are available in Table S2. For Phylogroups 1, 3 and 10 no unique open reading frames or unique DNA sequences were observed. For these phylogroups, DNA regions of some genes (Table 1) were used to design primers based on single nucleotide polymorphisms (SNPs). The SNP containing region was chosen based on a high $\mathrm{G} / \mathrm{C}$ content. The size of the SNPs on the forward $(\mathrm{Fw})$ and reverse $(\mathrm{Rv})$ primers varied from 4 to $17 \mathrm{bp}$ as reported in Table 1 .

PCR conditions and analysis of the amplicons for detection of $P$. syringae phylogroups

All primer pairs were tested individually. After verification of the specificity and the size of the amplicons, primer pairs were combined in multiplex PCRs in order to reduce the number of PCRs required to identify the phylogroups. Reaction mixes for the individual PCR were composed of $5.0 \mu 1$ of GoTaq green 5X PCR buffer (Promega, France), $1.5 \mu$ of a solution of $25 \mathrm{mmol} \mathrm{l}^{-1} \mathrm{MgCl}_{2}, 0.2 \mu 1$ of a mix of $25 \mathrm{mmol} \mathrm{l}^{-1} \mathrm{dNTPs}, 2 \mu \mathrm{l}$ of a mix of primers consisting of $10 \mathrm{mmol}^{-1} \mathrm{Fw}$ and Rv primers, $0.13 \mu 1$ of GoTaq G2 DNA polymerase (Promega, France) with 5 units $\mu 1^{-1}$, and $2.0 \mu 1$ of bacterial suspension at $10^{8}$ cells $\mathrm{ml}^{-1}$. The final volume of the PCR reaction was $25 \mu \mathrm{l}$ and milliQ water was

This article is protected by copyright. All rights reserved.

Borschinger, B., Bartoli, C., Chandeysson, C., Guilbaud, C., Parisi, L., Bourgeay, J.-F. 
used to mix dilution. All PCR amplifications were performed for 30 cycles; primer sequences and PCR conditions are listed in Table 2. Reaction mixes for the multiplex PCRs were composed of 6.25 $\mu 1$ of 2X QIAGEN Multiplex PCR Master Mix (Qiagen ${ }^{\circledR}$ Multiplex PCR kit), $1.25 \mu 1$ of primer mix with a final concentration of $2 \mathrm{mmol}^{-1}$ per primer, $1.25 \mu 1$ of Q solution, $2.75 \mu 1$ of milliQ water and $2.0 \mu \mathrm{l}$ of bacterial suspension at $10^{8}$ cells $\mathrm{ml}^{-1}$. The final volume reaction for the multiplex PCR was $11.5 \mu 1$. Taking into account the amplicon sizes (Table 2), two multiplex PCR reactions were developed: "Multiplex 1" containing the universal primer pair Psy and the primers specific for phylogroup 1 (PG1), phylogroup 3 (PG3) and phylogroup 9 (PG9) and "Multiplex 2" containing the primer pair Psy and those specific for phylogroup 2 (PG2), phylogroup 4 (PG4) and phylogroup 13 (PG13). Amplification was performed for 30 cycles and denaturation and elongation temperatures were $95^{\circ} \mathrm{C}$ and $72^{\circ} \mathrm{C}$, respectively for all reactions. Annealing temperatures are reported in Table 2 . PCR products were migrated at $80 \mathrm{~V}$ in a $1.5 \%$ agarose gel containing ethidium bromide (BET) (Euromedex, EU0070) at a concentration of $0.5 \mu \mathrm{g} \mathrm{m}{ }^{-1}$. Migration times varied depending on the size of PCR amplicons. After migration, PCR products were visualized under ultraviolet light (320 nm).

\section{Sensitivity and performance criteria}

To test the sensitivity of the multiplex PCR, different bacterial concentrations were used during PCR amplifications. These concentrations varied from $10^{8}$ to $10^{4}$ bacterial cells $\mathrm{ml}^{-1}$.

To test the performance of the PCRs we used criteria described in previous studies (EPPO 2010; 2014; Loreti et al. 2014). These performance criteria are derived from those used in the development of a PCR based detection method for P. syringae pv. actinidiae (Loreti et al. 2014). Briefly, these criteria include i) relative accuracy (A) which corresponds to the similarity of the observed results compared to expected results, ii) diagnostic sensitivity (SE) which is the ability of the method to detect the target strain in a contaminated reference sample, and iii) diagnostic specificity (SP) which corresponds to the capacity of the method to not yield a positive result in an uncontaminated sample reference.

This article is protected by copyright. All rights reserved. 


\section{Results}

Eight primer pairs are sufficient to identify nine $P$. syringae phylogroups

In this work, we developed primer pairs for the identification of 9 P. syringae phylogroups $(1,2,3,4$, 9, 10 and 13). A primer pair for the detection of the P. syringae phylogroups 7 and 8 was developed and evaluated previously (Bartoli et al, 2014).

To detect PG1, a primer pair was developed based on the inter-phylogroup variability found in the gyrase B (gyrB) housekeeping gene. The primer pair and the SNPs used to discriminate the PG1 strains among all the rest of the $P$. syringae phylogroups are reported in Table 1 and 2. Except for this primer pair all other primers were designed on non - housekeeping genes. The primer pair for PG1 (Table 2) was designed in the 387-754 bp region of the gyrB gene and amplify a fragment of 321 bp. The corresponding SNP localizations are reported in Table 1.

For PG2, a unique gene candidate (DUF421) was found in the 16 genomes used during this study. This gene codes for a domain with unknown function, according to the database of conserved protein domain families (Pfam04239). The PG2 primer pair (Table 2) was designed on the 21-404 bp region of the gene, and amplifies a fragment of $341 \mathrm{bp}$.

For PG3, a gene coding for a DUF1835 domain was found in all the available PG3 genomes and in some strains belonging to the phylogroups $1,7,9$ and 10 . This gene codes for a protein of unknown function and its domain is classed under the number pfam08874. Gene sequences for these four $P$. syringae phylogroups displayed a high degree of polymorphism. This polymorphism was used to design a specific primer pair that amplifies only PG3. The localizations of the SNPs used to design the specific PG3 primers are reported in Table 1. PG3 specific primer pair (Table 2) was developed on the 61-937 bp region of the gene and amplifies a fragment of $837 \mathrm{bp}$.

For PG4 one unique gene was found, coding for a lysine-tRNA ligase (pfam01921). The domain of this protein was only found in this P. syringae phylogroup. The sequences of the primer pair (Table 2) developed on the 605-1489 bp region of the gene amplify a fragment of $845 \mathrm{bp}$.

This article is protected by copyright. All rights reserved.

Borschinger, B., Bartoli, C., Chandeysson, C., Guilbaud, C., Parisi, L., Bourgeay, J.-F. 
For PG9 a gene involved in bacterial chemotaxis (pfam04509) was found to be specific for all the strains in this phylogroup. The primer pair (Table 2) for this $P$. syringae phylogroup was developed on the 41-469 bp region of the gene and amplifies a fragment of $389 \mathrm{bp}$.

For PG10 strains we did not identify a specific candidate gene. Therefore, we selected a gene coding for a DUF2599 domain (pfam10783) present in the genome of the 3 genomes available for the PG10 as well in one strain of the P. syringae PG1. The PG10 specific primer pair (Table 2) was developed on the 435-799 bp region of the gene and amplifies a fragment of $324 \mathrm{bp}$. Localizations of the SNPs that were used to discriminate between the two phylogroups (PG10 and PG1) are reported in Table 1. For PG13 several specific genes were found in the one available genome of a strain belonging to this phylogroup. The most accurate and specific primer pair targeted a gene encoding an alphaglucosidase (pfam01055). The primer pair (Table 2) developed on the 599-1220 bp region of the gene amplifies a fragment of $582 \mathrm{bp}$.

The primer pairs for detection of the nine $P$. syringae phylogroups are specific with a high level of sensitivity.

Results for the performance criteria demonstrated that the primer pairs we developed here for the detection of the nine $P$. syringae phylogroups are highly specific and sensitive (Table 3 ). In fact, we reported that SP is higher than $99 \%$ for all the primer pairs, indicating a high specificity level. Only one false positive PCR result was reported with the PG2 and PG13 primer pairs. All PCR results are available in Table S1. A 100\% SE was obtained for the phylogroups 2, 3, 9 and 13 primer pairs, indicating a good diagnostic sensitivity. Only 1 false negative PCR result was observed for the PG1 and PG4 primer pairs. The lowest diagnostic sensitivity was observed for the PG10 primer pair, only 8 of the 18 PG10 strains were amplified.

This article is protected by copyright. All rights reserved. 
Concerning sensitivity, i.e. the amount of bacterial cells $\mathrm{ml}^{-1}$ needed for positive PCR detection, clear bands were obtained in single and multiplex PCR on suspensions with at least $10^{6}$ bacterial cells ml ${ }^{-1}$, which corresponds to $2.10^{3}$ cells in the $2 \mu$ used for PCR reaction. Weak bands were obtained for bacterial suspensions at $10^{5}$ bacterial cells $\mathrm{ml}^{-1}$.

A blind test on putative $P$. syringae isolates from kiwifruit and apricot orchards showed the efficiency of the primer pairs in identifying PGs in natural samples

Phylogroup affiliation of 174 putative $P$. syringae isolates from kiwifruit and apricot orchards was determined in parallel by cts sequencing and with the PCR method. Results based on the primer pair detection method showed the following phylogroup affiliation: i) $31 \%$ of the isolates were in $P$. syringae PG1, ii) $14 \%$ of the isolates clustered with strains of PG2, iii) $8 \%$ of the isolates were located in PG7 and 8, iv) 29\% and 7\% of the isolates clustered in PG13 and with different bacterial species respectively (Figure 1a). Furthermore for $5 \%$ of the isolates the phylogroup affiliation could not be determined $(\mathrm{Ni})$ and in $6 \%$ of cases a multiple phylogroup identification (Mi) occurred (identification of 2 or more phylogroups for a same isolate) (Figure 1a). Through cts sequencing similar results were observed: i) $34 \%$ of the isolates were in the P. syringae PG1, ii) $14 \%$ of the isolates clustered with strains of PG2, iii) $1 \%$ of the isolates were in PG3, iv) $7 \%$ and $1 \%$ of the isolates were in PG7 and 8 respectively, v) $2 \%$ of the isolates were in PG9, vi) $4 \%$ of the isolates were in PG 10 , vii) $29 \%$ and $7 \%$ of the isolates clustered with PG13 and with different bacterial species respectively, and viii) $1 \%$ of the isolates remain without phylogroup identification (Figure 1b). For the isolates whose results did not match between the primer pair detection method and the cts sequencing, the cts sequences revealed that $4 \%, 2 \%, 3 \%$ and $2 \%$ of the strains for PG1, PG2, PG7 and PG13 respectively, were misidentified. None of the 7 isolates of PG10 were detected by the PCR method, they were misidentified as belonging to PG7-8 or to PG1. PCR characterization of 10 isolates revealed that they contained mixtures of 2 or more phylogroups. Purification led to the isolation of the predicted components of the mixture. Among the 9 isolates that could not be identified with PCR, based on the

This article is protected by copyright. All rights reserved.

Borschinger, B., Bartoli, C., Chandeysson, C., Guilbaud, C., Parisi, L., Bourgeay, J.-F. 
cts sequence of the purified strains six represented PG1, two represented PG9 and one could not be identified with the current phylogenetic classification. Twelve isolates did not belong to the species $P$. syringae according to the PCR results, and this was confirmed by sequencing the cts gene.

\section{Discussion}

The PCR markers developed in this study allow rapid classification and identification of the infraspecific diversity for at least 8 P. syringae phylogroups (PG1, 2, 3, 4, 7, 8, 9 and 13) with a high level of accuracy and for some of the strains in PG10. By coupling phylogroup-specific primer pairs to the P. syringae species-specific primer pair (Guilbaud et al. in press) and to a sensitive selective medium (Mohan and Schaad 1987), the structure of $P$. syringae populations associated with plants and other substrates can be quantified. Quantification can be easily performed by counting the number of colonies present on the $P$. syringae selective medium. From the bacterial isolates obtained by plating, classification of the strains into the corresponding P. syringae phylogroups is then possible by using the primer sets proposed here.

Identifying phylogroups, with a sequencing-free molecular technique, will lead to more efficient sequencing that targets only strains for which phylogroup affiliation is not possible. Targeted sequencing could therefore be focused on the more rare phylogroups such as the phylogroup $5,6,11$ and 12 as well as any currently unknown phylogroups that occurred in the samples. Understanding phylogroup affiliation of isolates is an important step for the identification of $P$. syringae lines implicated in a range of diseases. The method proposed here could be then employed for epidemiological studies aiming at characterizing $P$. syringae diversity associated with diseased plants. To date, the kiwifruit epidemic is known to be caused by strains of the P. syringae complex that belong to PG1 (Bartoli et al. 2015). By using the primers developed here, one can attempt to detect strains in the P. syringae PG1 associated with disease on kiwifruit plants and then to confirm with more specific primers their identity with the current quasi-clonal epidemic line. In this way association of other $P$. syringae phylogroups as an important factor for disease occurrence on kiwifruit could be revealed. For example, here we revealed the presence of strains belonging to PG10

This article is protected by copyright. All rights reserved.

Borschinger, B., Bartoli, C., Chandeysson, C., Guilbaud, C., Parisi, L., Bourgeay, J.-F. 
and PG13 as epiphytes on ground cover plants and in buds of apricot and kiwifruit orchards. Previously these phylogroups were only observed in water and other non-plant substrates associated with the water cycle (Berge et al. 2014). The potential synergistic or antagonistic roles of these phylogroups in symptom manifestation is unknown and can now be explored.

Furthermore the molecular technique described here leads to considerable time savings in light of the effort required for strain purification and preparation of DNA for sequencing. In fact, when the method is applied to isolates that have not been purified it is possible to identify mixtures of several phylogroups. However, it is not possible to determine the number of isolates of each phylogroup constituting these mixtures nor to identify mixtures of several strains of the same phylogroup.

The cases of misallocation of the phylogroups by PCR can be explained by the extreme genetic variability that exists within the $P$. syringae complex (Berge et al. 2014). Indeed some strains can lose or gain genes as a result of mutation, deletion or insertion. Developing primers to identify species of the same genus or genera sharing the same functions can sometimes be difficult, and differentiating strains within a bacterial species is often even more difficult (Romero et al. 1995; Wang et al. 1997; Hallin and Lindgren 1999; Kidd et al. 2009; Rees-George et al. 2010; Gallelli et al. 2014). The primer pairs described here should be used in two separate PCR protocols: two multiplexes - one to identify PG1, 3 and 9 and the second for identification of PG2, 4 and 13 - and two independent single PCRs. The first single PCRs will allow for the identification of strains in PG 7 and 8 with the specific primer pair (shcF) previously described (Bartoli et al. 2014). The primer pair shcF could not be incorporated into the multiplex due to incompatibility of the annealing temperatures. The second single PCR will allow the identification of strains in PG10. It was not possible to couple this last primer pair because the size of the amplicon, $324 \mathrm{bp}$, is similar to amplicons obtained for PG1 (321bp) and PG2 (341 bp).

The method described here will facilitate exploration of population structures of $P$. syringae assemblages and in particular in samples where different genetic lines co-exist and potentially interact. It will also contribute to the discovery and characterization of unknown $P$. syringae phylogroups in natural samples. With the increase in the number of available $P$. syringae genomes, improving molecular markers for $P$. syringae phylogroup detection is facilitated. The approach

This article is protected by copyright. All rights reserved.

Borschinger, B., Bartoli, C., Chandeysson, C., Guilbaud, C., Parisi, L., Bourgeay, J.-F. Buisson, E., Morris, C. E. (Auteur de correspondance) (2016). A set of PCRs for rapid identification and characterization of Pseudomonas syringae phylogroups. Journal of Applied Microbiology, 120 
proposed here will open new perspectives on the importance of assemblages of genotypes of this bacterium in its survival, fitness and pathogenicity.

Acknowledgements This work was partially supported by a grant from the French Ministry of Agriculture (contract n 21000480, “Amélioration des moyens de lutte contre Pseudomonas syringae $p v$ actinidiae”). The salary of $\mathrm{B}$. Borschinger was provided by a scholarship from the TERSYS research federation.

\section{Conflict of Interest}

The authors declare no conflict of interest.

\section{References}

Balestra, G.M., Taratufolo, M.C., Vinatzer, B.A. and Mazzaglia, A. (2013) A multiplex PCR assay for detection of Pseudomonas syringae pv. actinidiae and differentiation of populations with different geographic origin. Plant Dis 97, 472-478.

Barret, M., Briand, M., Bonneau, S., Préveaux, A., Valière, S., Bouchez, O., Hunault, G., Simoneau, P. and Jacques, M.-A. (2015) Emergence shapes the structure of the seed microbiota. Appl Environ Microbiol 81, 1257-1266.

Bartoli, C., Berge, O., Monteil, C.L., Guilbaud, C., Balestra, G.M., Varvaro, L., Jones, C., Dangl, J.L., Baltrus, D.A., Sands, D.C. and Morris, C. E. (2014) The Pseudomonas viridiflava phylogroups in the $P$. syringae species complex are characterized by genetic variability and phenotypic plasticity of pathogenicity-related traits. Environ Microbiol 16, 2301-2315.

Bartoli, C., Lamichhane, J.R., Berge, O., Guilbaud, C., Varvaro, L., Balestra, G.M., Vinatzer, B.A. and Morris, C.E. (2015) A framework to gauge the epidemic potential of plant pathogens in environmental reservoirs: the example of kiwifruit canker. Mol Plant Pathol 16, 137-149.

Berge, O., Monteil, C.L., Bartoli, C., Chandeysson, C., Guilbaud, C., Sands, D.C. and Morris, C.E. (2014) A user's guide to a data base of the diversity of Pseudomonas syringae and its application to classifying strains in this phylogenetic complex. PloS one 9, e105547.

Donati, I., Buriani, G., Cellini, A., Mauri, S., Costa, G. and Spinelli, F. (2014) New insights on the bacterial canker of kiwifruit (Pseudomonas syringae pv. actinidiae). J Berry Res 4, 53-67.

EPPO (2010) PM 7/98 (1): specific requirements for laboratories preparing accreditation for a plant pest diagnostic activity. Bull OEPP 40, 5-22.

EPPO (2014) PM 7/120 (1) Pseudomonas syringae pv. actinidiae. Bull OEPP 44, 360-375.

Gaignard, J.L. and Luisetti, J. (1993) Pseudomonas syringae, bactérie épiphyte, glaçogène et pathogène. Agronomie 13, 333-370.

This article is protected by copyright. All rights reserved. 
Gallelli, A., Talocci, S., L'Aurora, A. and Loreti, S. (2011) Detection of Pseudomonas syringae pv. actinidiae, causal agent of bacterial canker of kiwifruit, from symptomless fruits and twigs, and from pollen. Phytopathol Mediterr 50, 462-472.

Gallelli, A., Talocci, S., Pilotti, M. and Loreti, S. (2014) Real-time and qualitative PCR for detecting Pseudomonas syringae pv. actinidiae isolates causing recent outbreaks of kiwifruit bacterial canker. Plant Pathol J 63, 264-276.

Green, S., Laue, B., Fossdal, C.G., A'Hara, S.W. and Cottrell, J.E. (2009) Infection of horse chestnut (Aesculus hippocastanum) by Pseudomonas syringae pv. aesculi and its detection by quantitative real-time PCR. Plant Pathol J 58, 731-744.

Guilbaud, C., Morris, C.E., Barakat, M., Ortet, P. and Berge, O. Access to the diversity of Pseudomonas syringae populations facilitated by a PCR-based method of identification targeting the whole species complex. FEMS Microbiol Ecol, In press

Hallin, S. and Lindgren, P.-E. (1999) PCR detection of genes encoding nitrite reductase in denitrifying bacteria. Appl Environ Microbiol 65, 1652-1657.

Handelsman, J. (2004) Metagenomics: application of genomics to uncultured microorganisms. Microbiol Mol Biol Rev 68, 669-685.

Hirano, S.S., Charkowski, A.O., Collmer, A., Willis, D.K. and Upper, C.D. (1999) Role of the Hrp type III protein secretion system in growth of Pseudomonas syringae pv. syringae B728a on host plants in the field. Proc Natl Acad Sci USA 96, 9851-9856.

Hirano, S.S. and Upper, C.D. (1990) Population biology and epidemiology of Pseudomonas syringae. Anпu Rev Phytopathol 28, 155-177.

Kamoun, S. and Kado, C.I. (1990) A plant-inducible gene of Xanthomonas campestris pv. campestris encodes an exocellular component required for growth in the host and hypersensitivity on nonhosts. J Bacteriol 172, 5165-5172.

Kawaguchi, A., Inoue, K. and Inoue, Y. (2014) Biological control of bacterial spot on peach by nonpathogenic Xanthomonas campestris strains AZ98101 and AZ98106. J Gen Plant Pathol 80, 158-163.

Kerr, A. and Htay, K. (1974) Biological control of crown gall through bacteriocin production. Physiol Mol Plant Pathol 4, 37-44.

Kidd, T.J., Ramsay, K.A., Hu, H., Bye, P.T.P., Elkins, M.R., Grimwood, K., Harbour, C., Marks, G.B., Nissen, M.D. and Robinson, P.J. (2009) Low rates of Pseudomonas aeruginosa misidentification in isolates from cystic fibrosis patients. Eur J Clin Microbiol 47, 1503-1509.

King, E.O., Ward, M.K. and Raney, D.E. (1954) Two simple media for the demonstration of pyocyanin and fluorescin. J Lab Clin Med 44, 301-307.

Koh, Y.J. and Nou, I.S. (2002) DNA markers for identification of Pseudomonas syringae pv. actinidiae. Mol Cells 13, 309-314.

Lamichhane, J., Messéan, A. and Morris, C.E. (2015) Insights into epidemiology and control of diseases of annual plants caused by the Pseudomonas syringae species complex. J Gen Plant Pathol 81, 331-350.

Lamichhane, J.R., Varvaro, L., Parisi, L., Audergon, J.-M. and Morris, C.E. (2014) Disease and frost damage of woody plants caused by Pseudomonas syringae: seeing the forest for the trees. $A d v$ Agron 126, 235-296.

Lamichhane, J.R. and Venturi, V. (2015) Synergisms between microbial pathogens in plant disease complexes: a growing trend. Front Plant Sci 6, 385.

Loreti, S., Pucci, N., Gallelli, A., Minardi, P., Ardizzi, S., Balestra, G.M., Mazzaglia, A. and Taratufolo, M.C. (2014) The Italian inter-laboratory study on the detection of Pseudomonas syringae pv. actinide. Phytopathol Mediterr 53, 159-167.

Mohan, S.K. and Schaad, N.W. (1987) An improved agar plating assay for detecting Pseudomonas syringae pv. syringae and P. s. pv. phaseolicola in contaminated bean seed. Phytopathology 77, 1390-1395.

Monteil, C.L., Lafolie, F., Laurent, J., Clement, J.-C., Simler, R., Travi, Y. and Morris, C.E. (2013) Soil water flow is a source of the plant pathogen Pseudomonas syringae in subalpine headwaters. Environ Microbiol 16, 2038-2052.

Morris, C.E., Kinkel, L.L., Xiao, K., Prior, P. and Sands, D.C. (2007) Surprising niche for the plant pathogen Pseudomonas syringae. Infect Genet Evol 7, 84-92.

This article is protected by copyright. All rights reserved. 
Morris, C.E., Sands, D.C., Vanneste, J.L., Montarry, J., Oakley, B., Guilbaud, C. and Glaux, C. (2010) Inferring the evolutionary history of the plant pathogen Pseudomonas syringae from its biogeography in headwaters of rivers in North America, Europe, and New Zealand. MBio 1, 107-110.

Morris, C.E., Wen, A., Xu, X. and Di, Y.-B. (1992) Ice nucleation-active bacteria on Chinese cabbage in northern China: Population dynamics and characteristics and their possible role in storage decay. Phytopathology 82, 739-746.

Mosqueda-Cano, G. and Herrera-Estrella, L. (1997) A simple and efficient PCR method for the specific detection of Pseudomonas syringae pv phaseolicola in bean seeds. World J Microbiol Biotechnol 13, 463-467.

Moss, W.P., Byrne, J.M., Campbell, H.L., Ji, P., Bonas, U., Jones, J.B. and Wilson, M. (2007) Biological control of bacterial spot of tomato using hrp mutants of Xanthomonas campestris pv. vesicatoria. Biol Control 41, 199-206.

Rees-George, J., Vanneste, J.L., Cornish, D.A., Pushparajah, I.P.S., Yu, J., Templeton, M.D. and Everett, K.R. (2010) Detection of Pseudomonas syringae pv. actinidiae using polymerase chain reaction (PCR) primers based on the 16S-23S rDNA intertranscribed spacer region and comparison with PCR primers based on other gene regions. Plant Pathol J 59, 453-464.

Romero, C., Gamazo, C., Pardo, M. and Lopez-Goni, I. (1995) Specific detection of Brucella DNA by PCR. J Clin Microbiol 33, 615-617.

Sawada, H., Suzuki, F., Matsuda, I. and Saitou, N. (1999) Phylogenetic analysis of Pseudomonas syringae pathovars suggests the horizontal gene transfer of $\arg K$ and the evolutionary stability of hrp gene cluster. J Mol Evol 49, 627-644.

Sawada, H., Takeuchi, T. and Matsuda, I. (1997) Comparative analysis of Pseudomonas syringae pv. actinidiae and pv. phaseolicola based on phaseolotoxin-resistant ornithine carbamoyltransferase gene $(\arg K)$ and 16S-23S rRNA intergenic spacer sequences. Appl Environ Microbiol 63, 282-288.

Scortichini, M. (2005) The population structure of some plant pathogenic bacteria: an ecological and adaptive perspective. J Plant Pathol 87, 5-12.

Tamura, K., Stecher, G., Peterson, D., Filipski, A. and Kumar, S. (2013) MEGA6: Molecular Evolutionary Genetics Analysis Version 6.0. Mol Biol Evol 30, 2725-2729.

Vanneste, J.L. (2013) Recent progress on detecting, understanding and controlling Pseudomonas syringae pv. actinidiae: a short review. NZ Plant Prot 66, 170-177.

Vayssier-Taussat, M., Albina, E., Citti, C., Cosson, J.-F., Jacques, M.-A., Lebrun, M.-H., Le Loir, Y., Ogliastro, M., Petit, M.-A. and Roumagnac, P. (2014) Shifting the paradigm from pathogens to pathobiome: new concepts in the light of meta-omics. Front Cell Infect Microbiol 4, 29

Walker, A.W., Duncan, S.H., Louis, P. and Flint, H.J. (2014) Phylogeny, culturing, and metagenomics of the human gut microbiota. Trends Microbiol 22, 267-274.

Wang, R.F., Cao, W.W. and Cerniglia, C.E. (1997) A universal protocol for PCR detection of 13 species of foodborne pathogens in foods. J Appl Microbiol 83, 727-736.

Zaccardelli, M., Spasiano, A., Bazzi, C. and Merighi, M. (2005) Identification and in planta detection of Pseudomonas syringae pv. tomato using PCR amplification of hrpZ ${ }_{\mathrm{Pst}}$. Eur J Plant Pathol 111, 85-90.

This article is protected by copyright. All rights reserved. 
Table 1. Genes used for primer development

\begin{tabular}{|c|c|c|c|c|c|c|c|c|c|c|c|}
\hline Strain & $\begin{array}{c}\text { Genome Accession } \\
\text { Number }\end{array}$ & Gene ID & $\begin{array}{c}\text { Genomic } \\
\text { Range (bp) } \\
* *\end{array}$ & $\begin{array}{l}\text { Gene } \\
\text { length } \\
\text { (bp) }\end{array}$ & Protein Annotation & $\begin{array}{c}\text { Presence in } \\
\text { phylogroups } \dagger\end{array}$ & $\begin{array}{c}\text { Target } \\
\text { Phylogroups } \\
+\end{array}$ & $\begin{array}{c}\begin{array}{c}\text { Forward } \\
\text { primer } \\
\text { localization } \\
\text { (bp) }\end{array} \\
\end{array}$ & $\begin{array}{c}\begin{array}{c}\text { Reverse } \\
\text { primer } \\
\text { localization } \\
\text { (bp) }\end{array} \\
\end{array}$ & $\begin{array}{l}\text { SNP localisation (bp), } \\
\text { Fw primer } \S\end{array}$ & $\begin{array}{l}\text { SNP localisation } \\
\text { (bp), Rv primer } \S\end{array}$ \\
\hline $\begin{array}{c}\text { NCPPB } \\
1108\end{array}$ & GCA_000177495.1 & 648421386 & $1935-4352$ & 2418 & $\begin{array}{l}\text { DNA gyrase/topoisomerase } \\
\text { IV, subunit B }\end{array}$ & $\begin{array}{c}1,2,3,4,5,6 \\
7,8,9,10,11 \\
12,13\end{array}$ & 1 & $387-410$ & $732-754$ & $\begin{array}{c}387,390,391,393 \\
394,397,399,400 \\
405,408\end{array}$ & $\begin{array}{c}732,733,735,738 \\
741,744,747,750 \\
751,753\end{array}$ \\
\hline $\mathrm{CC} 1458$ & GCA_000452805.2 & 2506895564 & $4542-4985$ & 444 & $\begin{array}{c}\text { Protein of unknown function. } \\
\text { DUF421 domain }\end{array}$ & 2 & 2 & $21-43$ & $385-404$ & na & na \\
\hline $\begin{array}{l}\text { NCPPB } \\
3335\end{array}$ & GCA_000164015.2 & 648877554 & $\begin{array}{l}38103- \\
39338\end{array}$ & 1236 & $\begin{array}{l}\text { Protein of unknown function. } \\
\text { DUF1835 domain }\end{array}$ & $1,3,7,9,10$ & 3 & $61-80$ & $918-937$ & $\begin{array}{c}66,69,72,73,74,75 \\
78,79\end{array}$ & $\begin{array}{c}918,919,920,921, \\
922,923,924,926, \\
927,928,929,930, \\
931,933,934,935, \\
936\end{array}$ \\
\hline CC1513 & GCA_000452765.2 & 2506907413 & $\begin{array}{l}8421- \\
11348\end{array}$ & 2928 & $\begin{array}{l}\text { Lysyl-tRNA synthetase, class } \\
\text { I }\end{array}$ & 4 & 4 & $605-624$ & $1470-1489$ & na & na \\
\hline CC1417 & GCA_000452825.2 & 2506965122 & $7504-8115$ & 612 & Chemotaxis like protein & 9 & 9 & $41-60$ & $450-469$ & na & na \\
\hline CC1466 & GCA_000452785.2 & 2506901715 & $\begin{array}{l}17733- \\
18980\end{array}$ & 1248 & $\begin{array}{l}\text { Protein of unknown function. } \\
\text { DUF2599 domain }\end{array}$ & 1,10 & 10 & $435-458$ & $780-799$ & $\begin{array}{c}435,443,447,448 \\
456,458\end{array}$ & $780,786,795,798$ \\
\hline UB246 & GCA_000452865.1 & 2507270264 & 7514-9898 & 2385 & $\begin{array}{l}\text { Alpha-glucosidase, glycosyl } \\
\text { hydrolase family GH31 }\end{array}$ & 13 & 13 & $599-618$ & $1201-1220$ & na & na \\
\hline
\end{tabular}

* Range of the gene that was used to design the primer pairs.

$\dagger$ Phylogroup in which the gene was present as single copy.

¥ The given gene was used to develop specific primers for the phylogroups listed in the table.

$\S$ SNP localization refers to those genes that were present in more than one phylogroup.

This article has been accepted for publication and undergone full peer review but has not been through the copyediting, typesetting, pagination and proofreading process which may lead to differences between this version and the Version of Record. Please cite this article as an 'Accepted Article', doi: 10.1111/jam.13017

This article is protected by copyright. All rights reserved. 
Table 2. Primers and PCR conditions used for identification of Pseudomonas syringae phylogroups

\begin{tabular}{|c|c|c|c|}
\hline \multicolumn{4}{|c|}{ Simplex PCR } \\
\hline Primer Pairs & $\begin{array}{l}\text { Annealing temperatures } \\
\left({ }^{\circ} \mathrm{C}\right)\end{array}$ & $\begin{array}{l}\text { Expected size } \\
\text { (bp) }\end{array}$ & References \\
\hline \multicolumn{4}{|l|}{ Psy generic P. syringae primers } \\
\hline \multicolumn{4}{|l|}{ Fcb43 ATC ATG GGA GAC GCG CTT AAG } \\
\hline Rcb43 GCT GCA GAG AGC ACT & 61 & 144 & Guilbaud et al. in press \\
\hline \multicolumn{4}{|l|}{$\begin{array}{l}\text { PG1 } \\
\text { PG1-Fw AGA ACT TCT GTT GCT GAC } \\
\text { AGT ACG } \\
\text { PG1-Rv CAA TAC CGT CAT CGC GCT } \\
\text { GGA CA }\end{array}$} \\
\hline \multicolumn{4}{|l|}{$\begin{array}{l}\text { PG2 } \\
\text { PG2-Fw AGC AGC GAT TTA TTT TGT CTT } \\
\text { GA }\end{array}$} \\
\hline PG2-Rv ATG ATC GCG TAC CTG ATG TC & 60 & 341 & This study \\
\hline \multicolumn{4}{|l|}{ PG3 } \\
\hline \multicolumn{4}{|l|}{ PG3-Fw AAG CGT GCC AAA GAG CTT CT } \\
\hline PG3-Rv CTT GGC CGA AGG TCA TTG AC & 61 & 837 & This study \\
\hline \multicolumn{4}{|l|}{ PG4 } \\
\hline \multicolumn{4}{|l|}{ PG4-Fw CAC CTG ACT TAC TGA TCA AT } \\
\hline PG4-Rv ACA GGC ACG CAT ATA TCG TT & 60 & 845 & This study \\
\hline \multicolumn{4}{|l|}{ PG7 and $8($ shcF $)$} \\
\hline shcF-Rv TCA ATA CTC TGG AGA TCA G & 54 & 850 & Bartoli et al. 2014 \\
\hline \multicolumn{4}{|l|}{ PG9 } \\
\hline \multicolumn{4}{|l|}{ PG9-Fw CAT TGC AGG AAC TGA TGA AC } \\
\hline PG9-Rv GGT TCA ACT CTT CGA GAC AA & 58 & 389 & This study \\
\hline \multicolumn{4}{|l|}{$\begin{array}{l}\text { PG10 } \\
\text { PG10-Fw CAC GAC GAC CTA TAT TGA } \\
\text { AAA AAC } \\
\text { PG10-Rv CAG GGA CCC ATT TGC CGG }\end{array}$} \\
\hline $\begin{array}{l}\text { PG13 } \\
\text { PG13-Fw GGA TGT TCT ACG ACA ACC } \\
\text { TG } \\
\text { PG13-Rv AGC TGC GAG GTG ACG TTT } \\
\text { GA }\end{array}$ & 60 & 582 & This study \\
\hline \multicolumn{4}{|c|}{ Multiplex PCR } \\
\hline Multiplex 1 and $2 *$ & 61 & see above & This study \\
\hline
\end{tabular}

This article is protected by copyright. All rights reserved.

Borschinger, B., Bartoli, C., Chandeysson, C., Guilbaud, C., Parisi, L., Bourgeay, J.-F. 
Table 3. Specificity and sensitivity of the primers tested with individual primer pairs

\begin{tabular}{ccccccccc}
\hline $\begin{array}{c}\text { Target } \\
\text { Phylogroups }\end{array}$ & $\begin{array}{c}\text { Number of } \\
\text { strains tested }\end{array}$ & PA & PD & ND & NA & $\begin{array}{c}\text { Relative } \\
\text { accuracy, A } \\
(\%)\end{array}$ & $\begin{array}{c}\text { Diagnostic } \\
\text { sensitivity, SE (\%) }\end{array}$ & $\begin{array}{c}\text { Diagnostic } \\
\text { specificity, SP } \\
(\%)\end{array}$ \\
\hline \hline PG 1 & 131 & 24 & 0 & 1 & 106 & 99 & 96 & 100 \\
PG 2 & 157 & 38 & 1 & 0 & 119 & 99 & 100 & 99 \\
PG 3 & 132 & 17 & 0 & 0 & 115 & 100 & 100 & 100 \\
PG 4 & 167 & 7 & 0 & 1 & 159 & 99 & 87 & 100 \\
PG 9 & 138 & 14 & 0 & 0 & 124 & 100 & 100 & 100 \\
PG 10 & 131 & 8 & 0 & 10 & 113 & 92 & 44 & 100 \\
PG 13 & 191 & 34 & 1 & 0 & 157 & 99 & 100 & 99 \\
\hline
\end{tabular}

$\mathrm{PA}=$ positive agreement, or the number of positive results obtained with a sample containing the targeted phylogroup

$\mathrm{PD}=$ positive deviation (false positive), or the number of positive results obtained with a sample that did not contain the targeted phylogroup

$\mathrm{ND}=$ negative deviation (false negative), or the number of negative results obtained with a sample that contained the targeted phylogroup

$\mathrm{NA}=$ negative agreement, or the number of negative results obtained with a sample that did not contain the targeted phylogroup

$\mathrm{A}=100 \% *[(\mathrm{PA}+\mathrm{NA}) /(\mathrm{PA}+\mathrm{PD}+\mathrm{ND}+\mathrm{NA})]$

$\mathrm{SE}=100 \%[\mathrm{PA} /(\mathrm{PA}+\mathrm{ND})]$

$\mathrm{SP}=100 \% *[\mathrm{NA} /(\mathrm{NA}+\mathrm{PD})]$

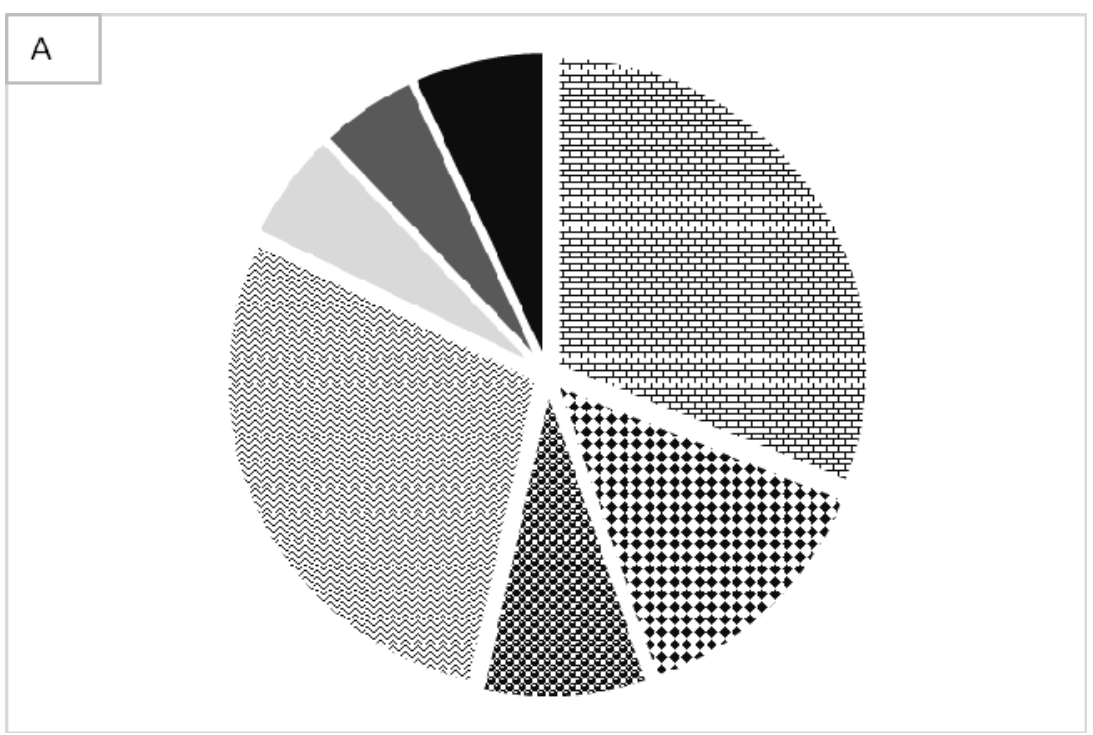

This article is protected by copyright. All rights reserved.

Borschinger, B., Bartoli, C., Chandeysson, C., Guilbaud, C., Parisi, L., Bourgeay. J.-F. 


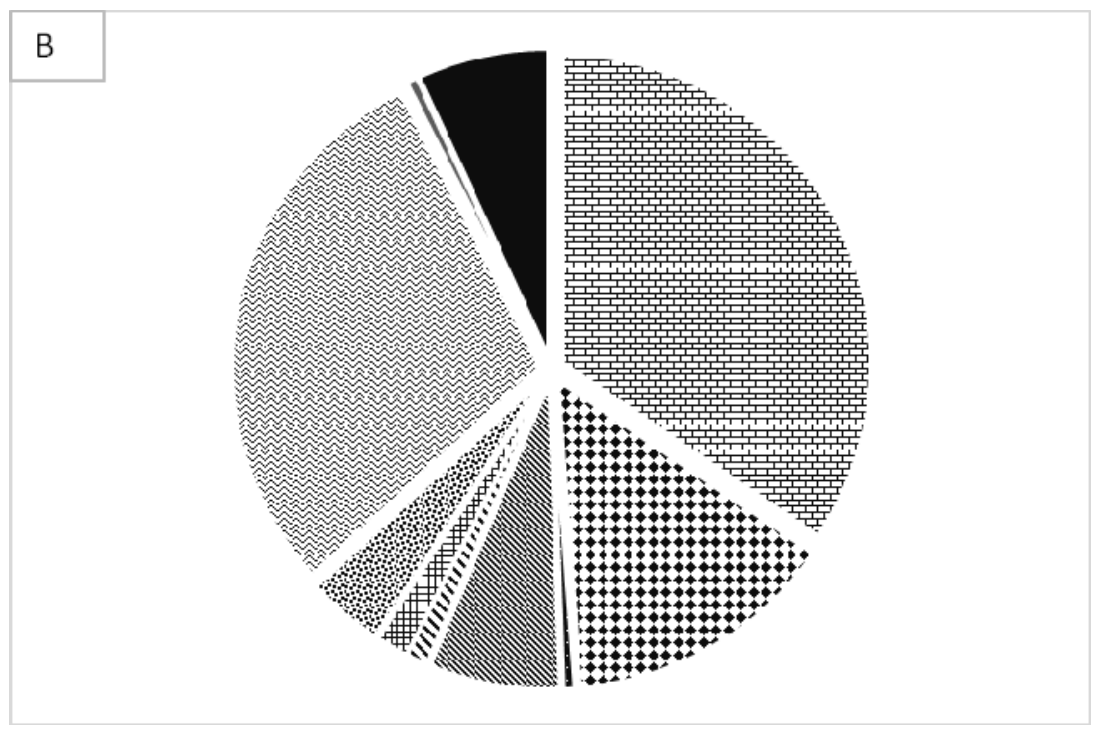

Figure 1. Relative proportion of Pseudomonas syringae phylogroups (PG1而, $\mathrm{PG} 2 \&$, PG3閏, PG7M, PG8NW, PG7/8\%, PG9 from Southeastern France. Results based on the PCR primers described in this work (A) were compared with those obtained by phylogenetic analysis based on sequences the $c t s$ gene (B). For some isolates the phylogroup could not be determined $(\mathrm{Ni}-$ ) or they were assigned to multiple phylogroups because they were composed of several strains (Mi isolates tested didn't belong to the $P$. syringae species (NP $\square$ ).

\section{Table S1}

List of strains used during this study and related information.

\section{Table S2}

List of the gene sequences used during this study.

This article is protected by copyright. All rights reserved. 